Rapp. Grønlands geol. Unders. 81, 5-14 (1977)

\title{
IRON-BEARING AND RELATED VOLCANIC ROCKS IN THE AREA BETWEEN GIESECKES DAL AND HAMMERS DAL, NORTH-WEST DISKO
}

\author{
Asger Ken Pedersen
}

\section{Introduction}

This paper reports the results of about three weeks investigations in the summer of 1974 in the area between Gieseckes Dal and Hammers Dal, north-west Disko. The area was previously poorly known. Short accounts are given by Münther $(1952,1973)$, who discovered two volcanic necks with native iron bearing rocks south of Gieseckes Dal. Henderson (1973) has made photogeological work, and V. Münther has compiled an unpublished map of the region. The area is poorly exposed so that the photogeological compilation of the area on the geological map sheet $70 \mathrm{~V} .1 \mathrm{~S}$, Qutdligssat is incomplete.

Behind a flat coastal belt of marine terraces, the terrain rises slowly, and exposures are mostly confined to narrow valleys and gorges (fig. 1). From Keglerne and towards the east, the pre-Quaternary is better exposed and gradually develops into a typical plateau basalt landscape with strong topographic relief.

Pedersen (1975) described the area from Hammers Dal and southwards and the general stratigraphy is summarized here as Table 1 . In total about 2 to $2.5 \mathrm{~km}$ of rocks from the Maligât Formation have been preserved in the area.

Table 1. Summary of basalt stratigraphy in north-western Disko

\begin{tabular}{ll}
\hline Niaqussat member & $\begin{array}{l}\text { Feldsparphyric basalts } \\
\text { Olivine-porphyritic, contaminated basalts } \\
\text { Iron-bearing contaminated basaltic and andesitic lavas }\end{array}$ \\
\hline Nordfjord member & $\begin{array}{l}\text { Feldspar-porphyritic basalt, slightly contaminated } \\
\text { Conglomerates and sandstones, sometimes with plant remains } \\
\text { Quartz crystal tuff, redeposited, with blocks of almandine-bearing dacite } \\
\text { and rhyolitic pitchstone } \\
\text { Contaminated basalts } \\
\text { Graphite-bearing acid pumice tuffs } \\
\text { Iron-bearing contaminated basaltic and andesitic lavas }\end{array}$ \\
\hline Rinks Dal member & Feldsparphyric plateau basalts \\
\hline Faigat & $\begin{array}{l}\text { Picrite basalts } \\
\text { Olivine and feldsparphyric basalts }\end{array}$ \\
\hline
\end{tabular}


While most of northern and eastern Disko was only slightly affected by post-emplacement tectonics, the area described here suffered extensive faulting and vertical movements of up to several kilometres. The area from Hammers Dal and northwards to the canyon east of Igdlorpait was cut into numerous blocks along $\mathrm{N}$ to $\mathrm{NW}$ striking faults, with extensive repetition in the lavas. These show dips increasing from less than $5^{\circ} \mathrm{W}$, east of Keglerne, up to $35-40^{\circ} \mathrm{W}$ near the coast. The same pattern was found south of Hammers Dal (Pedersen, 1975 , plate 2). When moving northwards from the canyon east of Igdlorpait, the former lava plateau has been cut into blocks dipping from $10^{\circ}$ to 0 . Also here extensive vertical moments occurred, but the blocks are much larger and displacements between neighbouring blocks mostly smaller.

A simplified geological map is presented as fig. 2. Over considerable parts of the area the present knowledge is fragmentary due to poor exposures and complex geology and awaits very detailed mapping. In the following a number of geological features which characterize the volcanism of the reduced and often iron-bearing volcanic rocks from this part of Disko is described.

\section{Acid volcanism of the Nordfjord member}

The volcanic rocks of the Nordfjord member represent a wider range in chemical composition than any other volcanic sequence on Disko. They include feldsparphyric contaminated basalts, strongly contaminated basalts and andesites with iron, garnet dacite and rhyolite. Nearly all the volcanic products are lavas, only the acid volcanism was predominantly explosive. Tuffs are extremely scarce apart from the acid rocks. Since detailed knowledge of the sequence is incomplete, the following description is confined to the acid volcanic rocks which constitute less than 10 per cent of the member.

Two acid units are known. The lower unit was deposited on feldsparphyric slightly contaminated tholeiitic basalts after a period of stagnating volcanic activity (fig. 3 ). This is indicated by the formation of thin sedimentary beds with fossil plants and lignite. The acid rocks form a tuffaceous sequence about 4 to $6 \mathrm{~m}$ thick throughout the area. A schematic section through these tuffs is shown as fig. 4. The tuffs record at least 7 to 8 individual explosive events. Two thin horizons within the tuffs contain clay with plant fossils and show that at least some months or more likely years separated several of the explosive events. Most voluminous are white to grey tuffs rich in fragments of white pumice, derived from a rhyolitic magma. Characteristic local marker horizons within the tuffs are two dark grey layers, dominated by a graphite-rich acid pumice. They also contain graphite-free white pumice with quartz and feldspar phenocrysts, vesicle-poor acid glass and felsite which may have preserved biotite in addition to quartz and feldspar. Rare xenoliths of plagioclase with graphite have also been found. Numerous fragments of tholeiitic basalts are also included.

At some localities circulating water has altered the tuffs, and the resulting coloured, often green soft clays can be packed with residual, euhedral quartz phenocrysts, 0.5 to $1 \mathrm{~mm}$ in size.

The tuffs are overlain by a number of feldsparphyric basalt flows some of which are slightly contaminated with sandstone and shale sediments while others are distinctly contaminated. 


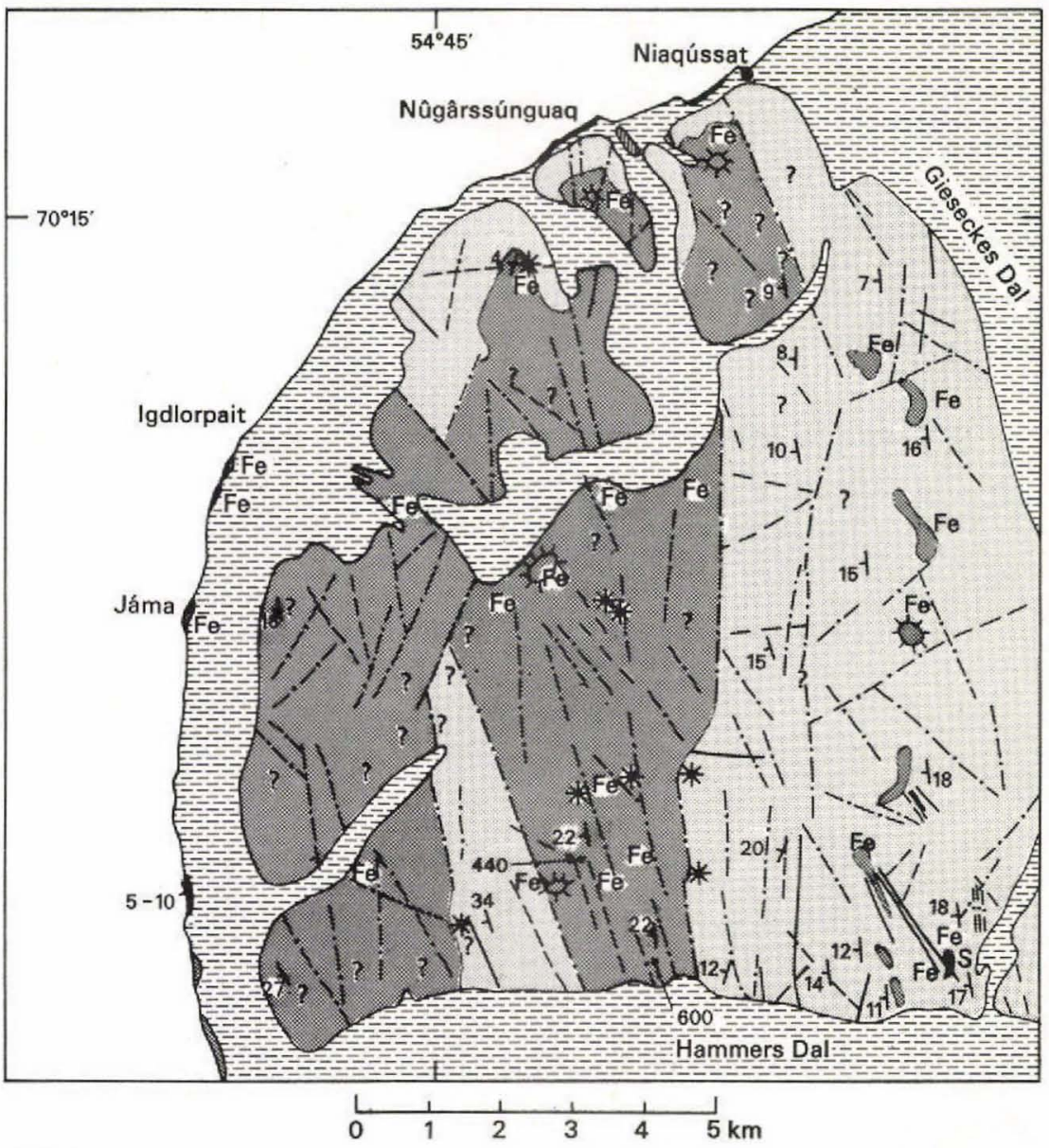

Sediment contaminated volcanic rocks from Niaqussat and Nordfjord members

Feldsparphyric basalts from Rinks Dal member

Olivine-rich basalt from Vaigat Formation

Quaternary cover

Basaltic dyke

Fault

Volcanic neck or crater

Fault, uncertain, or prominent joint $\quad \mathrm{Fe} \quad$ Native iron

Strike and dip

* Acid tuffs and conglomerates

Fig. 2. Geological map of the area between Gieseckes Dal and Hammers Dal, modified from the 1:100 000 geological map sheet Qutdligssat 70 V.1 Syd. 


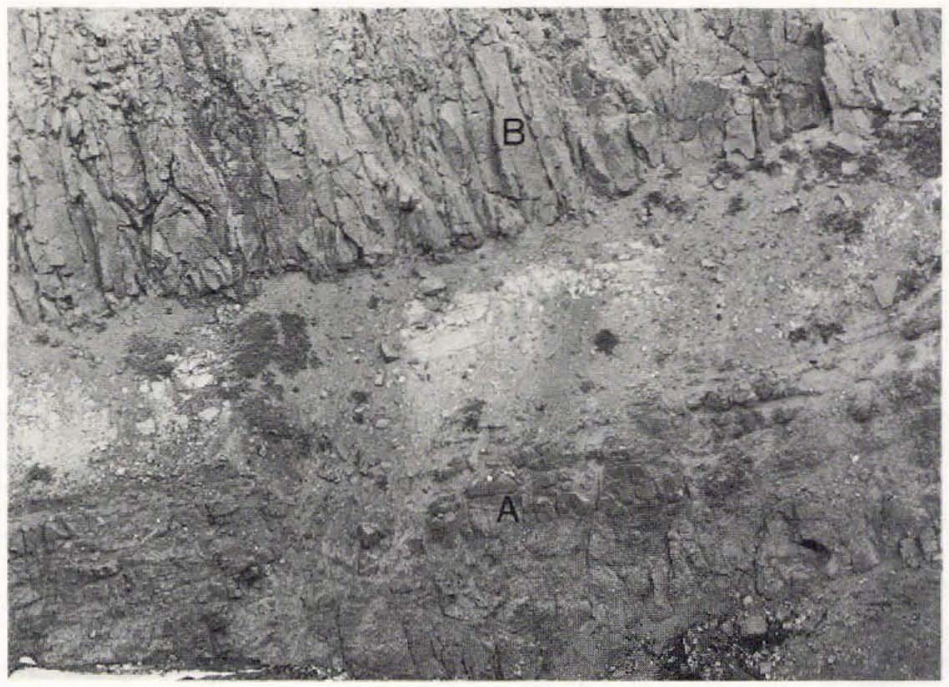

Fig. 3. The four metres thick sequence of white quartz prophyritic pumice tuff in Nordfjord member. A: feldsparphyric basaltic pahoehoe lava. B: feldsparphyric basaltic aa lava. Valley $1 \mathrm{~km} \mathrm{NNE}$ of the point 440 crater.

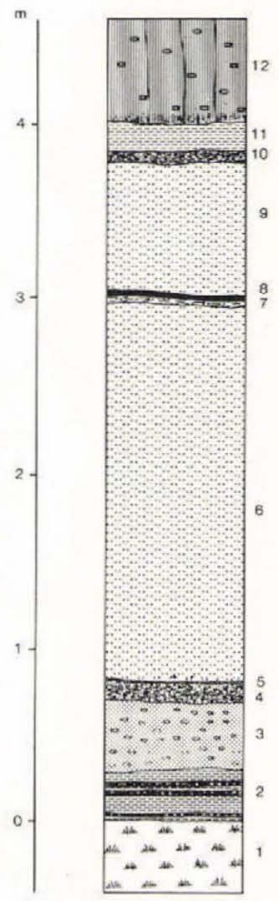

\section{Feldsparphyric basalt}

11 White tuff, weathered to laminated clay or siltstone

10 Acid pumice tuff with black graphite-rich and white graphite-free fragments

9 White rhyolitic pumice tuff

8 Shale sediment with plant remains

7 Weathered top of pumice tuff, with plant remains

6 White rhyolitic pumice tuff

\section{Thin red bole}

4 Acid pumice tuff with black graphite-rich and white graphite-free fragments

3 Yellow grey pumice tuff

2 Greenish-weathering altered tuff with intercalated coarse layers

1 No exposures

Fig. 4. A section through the white rhyolitic tuff sequence in Nordfjord member. A number of separate explosive events are recorded and weathering of the basal part and two thin sediment seams with traces of fossil plants indicate that the acid explosive center was active during a period exceeding a few years. Locality as fig. 3 . 
The upper of the two acid units is composed of tuffs which are mostly strongly reworked to sandstones and conglomerates. Such beds were first found by V. Münther \& A. Rosenkrantz (personal communication, 1968) in the southwestern part of Hammers Dal. The sequence may reach $6 \mathrm{~m}$ in thickness and has been recognized to the south and north of Hammers Dal. Generally, the beds clearly contain water-transported material and the sediments show strong sorting (fig. 5). The sequence may be covered by a decimetre thick layer of finely laminated clay or siltstone. The conglomerate blocks are mostly well rounded and vary in size from locality to locality. From maximum sizes of about $60 \mathrm{~cm}$ just south of Hammers Dal, the block size decreases towards the north. The block size variation indicates that the eruption sites for the upper acid unit were either somewhere in the poorly exposed areas in the outermost part of Hammers Dal or in the shallow sea just to the west of that valley.

Four types of blocks are found: (1) feldsparphyric to nearly aphyric basalt, (2) native iron bearing basalts and intermediate rocks, (3) garnet dacite, and (4) biotite pitchstone, flow laminated rhyolite, and biotite and quartz porphyritic pumice.

The garnet dacite is a blue grey to reddish porphyritic non-vesicular rock, which may show flow lamination. It contains phenocrysts of quartz, plagioclase, biotite, orthopyroxene, garnet and apatite and in addition sillimanite, corundum and modified graphite-rich shale xenoliths. The garnet is a deep red almandine, and the fact that it has been observed intergrown in the margin of shale xenoliths precludes any speculations of a high-pressure origin.

The pitchstones are dark grey to black rhyolitic glasses with scattered phenocrysts of quartz, plagioclase, sanidine, biotite and Fe-Ti oxides.

Xenoliths seem to be rare. The widespread occurrence of non-vesicular acid blocks, originating from at least two different magmas is a strong indication of eruption, where explosive phases were followed by effusive volcanism. It seems likely, that small acid necks or domes have existed.

Fig. 5. The lower part of the conglomerate and sandstone beds of reworked acid rocks. At bottom of the photograph is seen well sorted sandstone. Higher up, conglomerate with well rounded blocks of pitchstone, pumice, dacite and basalt. From little east-west extending valley about $1.4 \mathrm{~km}$ north of point 600 north of Hammers Dal.

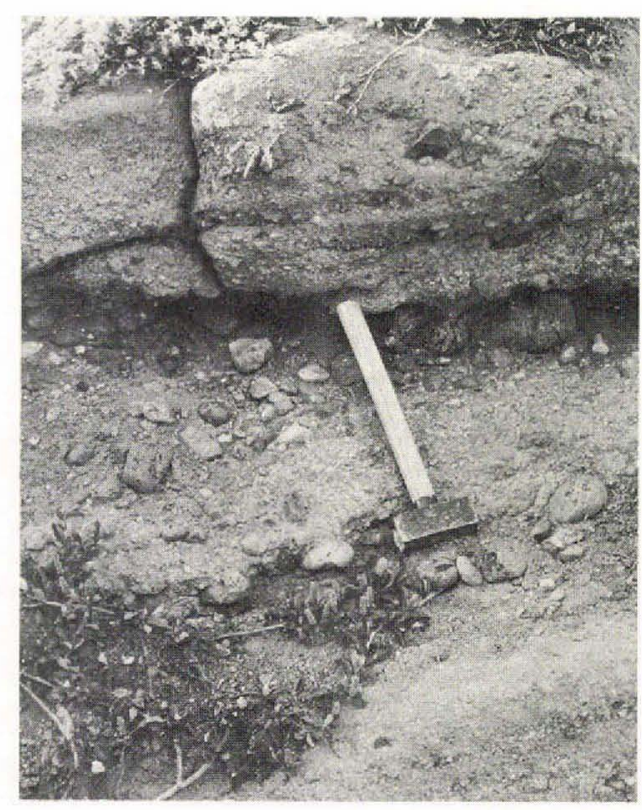




\section{Summary of the acid volcanism}

Although the acid volcanic rocks are so scarce, and the field evidence rather fragmental, they provide useful information on the volcanic evolution. At an early stage of the Nordfjord member volcanism, high level magma chambers were formed. Magmas upwelling from depth, with compositions similar to feldsparphyric basalts, were trapped in sediments underlying the volcanic formations. After the eruption of early formed sediment contaminated basalts and intermediate rocks, some of which became iron-bearing through natural reduction processes, stagnating eruptive conditions enabled coupled fractionation and contamination processes to proceed to highly evolved rhyolitic magmas, saturated with quartz. High gas pressures must have been built up and led to the most violent explosive eruptions found in the volcanic sequence of Disko. The characteristic graphite pumice horizons show that considerable amounts of organic compounds were incorporated in the acid magmas.

The garnet dacite and the quartz, feldspar and biotite porphyritic rhyolite seems to represent late stages in the magmatic evolution where highly reduced iron-bearing andesitic magmas while still reacting with carbon-rich reducing sediments through continued evolution and accumulation of $\mathrm{H}_{2} \mathrm{O}$ became progressively oxidized to leave the iron stability field in $T-f_{\mathrm{O} 2}$ space. A petrological investigation is therefore in progress to trace this interesting transition.

\section{Iron-bearing volcanic rocks from the lower part of the Niaqussat member}

The lower part of the Niaqussat member forms a more than $250 \mathrm{~m}$ thick sequence dominated by highly contaminated lavas, and contains by volume more native iron bearing rocks than found anywhere else. Fig. 2 shows the eruption sites of the iron-bearing rocks from this member. It is highly probable that several more remain undiscovered or unexposed.

The broad outlined iron-bearing volcanic rocks occur as three units, which are covered by a sequence of iron free but contaminated basalts. In detail the iron-bearing rocks show a complex geology, but this will be neglected here. Figs $6 \& 7$ illustrate a nearly undisturbed $245 \mathrm{~m}$ thick section through the iron lavas. Within the sequence, tuffs constitute only about 5 per cent of the volcanic products, which is much more than is found in the underlying uncontaminated plateau basalts on Disko.

The lower unit is composed of a few thin basaltic lavas covered by one or several thick lava flows of iron-bearing intermediate rock. Some of the thin basaltic lavas may have preceded the thick flows as the initial phases of an eruption, as observed in south-west Disko (Pedersen, 1975; this report). Two of the craters from which the thick lavas flowed were recorded by Münther (1952) just south of Gieseckes Dal. The lavas may reach a thickness of about $140 \mathrm{~m}$. They are mostly non-vesicular rocks forming coarse columns. The uppermost parts of the flows have a typical aa morphology and consist of a heap of non-vesicular, nearly glassy blocks and oxidized vesicular masses.

The rocks have a dense, nearly glassy groundmass in which native iron and sulphides may be very finely disseminated as less than $0.1 \mathrm{~mm}$ sized globular grains or may occur as larger but more scattered bodies up to $1 \mathrm{~mm}$ in size. The rock is strongly porphyritic with less than one millimetre sized orthopyroxene and plagioclase crystals dominating. In addi- 
Height above the base

of Niaqussat member

in meters

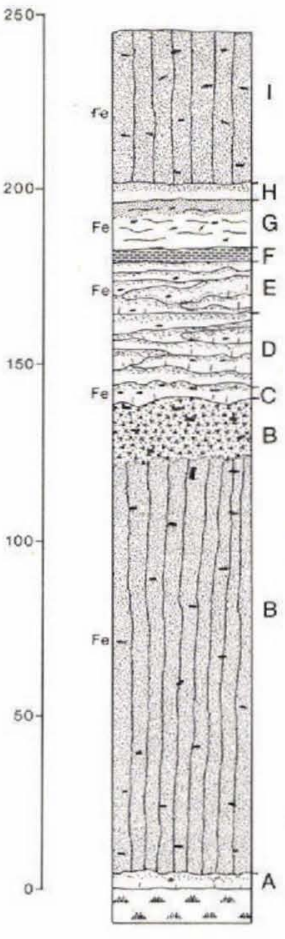

$\longleftarrow$ Fig. 6. Section through $245 \mathrm{~m}$ of Niaqussat member lavas at point 600 north of Hammers $\mathrm{Dal}$ with the lower unit $(\mathrm{A}+\mathrm{B})$, the middle unit $(\mathrm{C}$ $-\mathrm{H}$ ) and the upper unit (I) in the iron-bearing volcanic sequence. A: contaminated basalt, B: thick iron-bearing adesite, C, D and E: ironbearing basaltic and andesitic aa lavas, F: tuff of andesitic composition, $\mathrm{G}$ : iron-bearing andesite, $\mathrm{H}$ : strongly vesicular contaminated lava, $\mathrm{I}$ : thick graphite-rich iron-bearing andesite. Fe: native iron bearing lava.

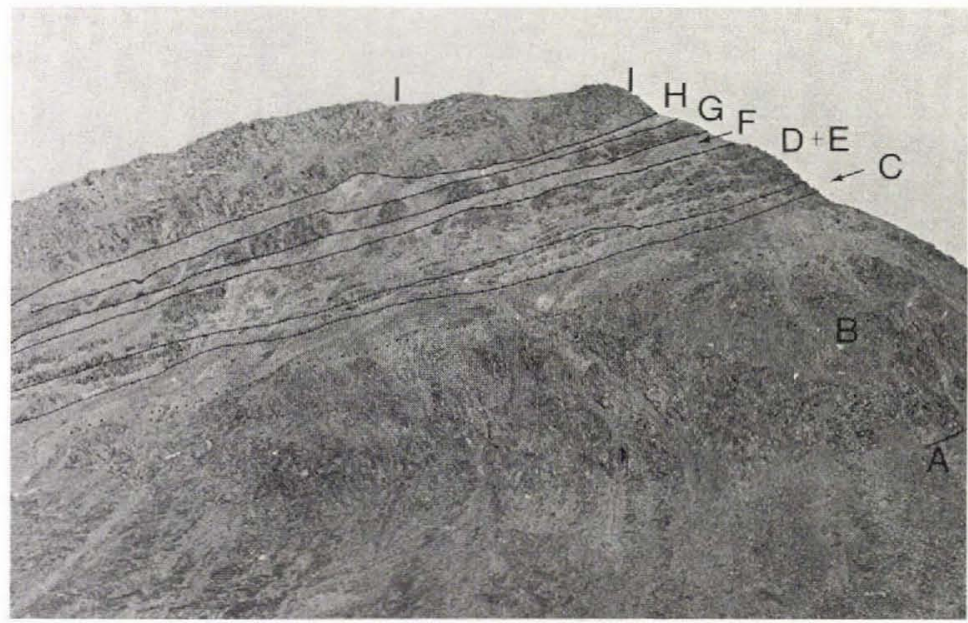

Fig. 7. Photograph of the section of fig. 6 at the point 600 . Letters A to I represent the same lava and tuff units as fig. 6 . The lavas are dipping $22^{\circ} \mathrm{W}$.

tion are found cognate inclusions of norite, numerous xenocrysts of olivine, spinel, corundum, cordierite, mullite, plagioclase, quartz and graphite together with modified sandstone and shale xenoliths.

The middle unit comprises a varied assemblage of contaminated basalts with and without native iron, a few metre thick beds of intermediate to basaltic tuff and native iron bearing intermediate lavas. The lavas are usually less than 10 metres thick aa lavas with an irregular surface oxidized in yellow to red colours.

The interior of the lavas are mostly strongly vesicular and the iron and sulphides, if present, are mostly weathered. Often it is evident that many lava flows belong to the same eruption. In total the middle unit can contain from less than 10 to more than 20 lava tongues. The lavas generally contain abundant modified sediment xenoliths which may be up to $70 \mathrm{~cm}$ in size (fig. 8). Shale xenoliths may have retained a platy shape. Often cognate noritic inclusions are found. The basic lavas tend to show sediment xenolith cumulation in the top zones, while iron and sulphides tend to occur as segregations of up to a few centimetres which have accumulated at the base of the flows. The lava sequence is especially well exposed in a deep canyon section east of Igdlorpait and seems to have had an eruption site within that area.

The upper unit in the southern part of the area comprises a more than $50 \mathrm{~m}$ thick iron-bearing lava, while in other parts of the area strongly contaminated basalts and tuffs are found instead. 


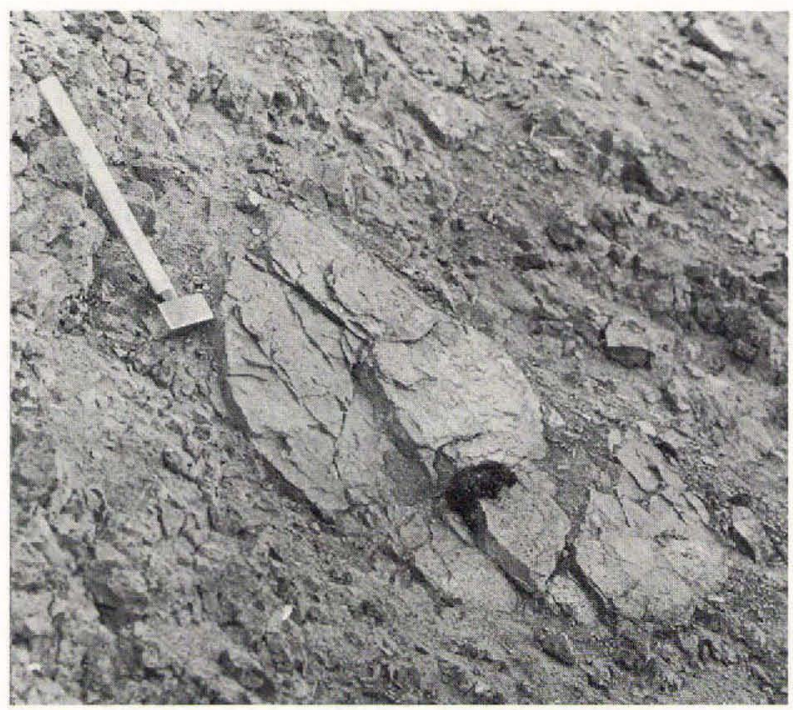

Fig. 8. Large xenolith of modified shale from the top of an iron-bearing aa lava from the middle unit. The xenolith splits into thin flakes parallel to the original sedimentary lamination.

The point 600 section.

The eruption site for the thick lava has been discovered near point 440 north of Hammers Dal, where a stream gorge exposes a section through a crater, partially disturbed by faulting. Since this is one of the very few exposed craters in the Tertiary volcanic province of West Greenland and since it illustrates the native iron volcanism, it will be described in some detail (fig. 9).

The crater dips steeply towards the west and rests on basaltic lavas from the middle unit. The two-dimensional section shows parts of two volcanic cones, which were at least 100 to $120 \mathrm{~m}$ high. A mushroom-shaped feeder body is seen in one of the crater bodies composed of a vesicle-poor dense intermediate rock with disseminated iron and rich in sedimentary xenoliths, grading towards the distal parts into a white-grey to reddish strongly vesicular nearly pumiceous rock. The latter grades further into a crater breccia, which forms most of the crater. The breccia sometimes shows a size gradational layering of fragments, which may be parallel to the crater surface. In the fine-vesicular rocks, several generations of oxidized earlier iron-bearing rock can be seen forming 'xenoliths' in progressively younger outflows from the crater centre. Well shaped bombs have not been observed.

Since no thick blanket of tuff has been observed in connection with the crater, it can safely be concluded that only a moderate gas-pressure prevailed in the high level magma chamber prior to the eruption, and much less than that in the chambers which gave rise to the acid tuffs found in the underlying Nordfjord member.

The thick iron lava erupted from the crater can be seen uphill towards point 440 , and an identical lava forms the top of the section at point 600 (fig. 6). Under the microscope the rock has a characteristic very fine-grained inhomogeneous groundmass rich in minute graphite flakes and dispersed iron and sulphide grains. Abundant phenocrysts of orthopyroxene and plagioclase less than $2 \mathrm{~mm}$ are found together with characteristic fine-grained orthopyroxene-plagioclase dolerite, which often forms caps on graphite-rich modified sediment xenoliths. Relic olivine with included chromite and capped by orthopyroxene occurs. Abundant xenocrysts derived from modified xenoliths are found. 
West of the crater, in a relatively uplifted fault block of feldsparphyric basalt flows from the Rinks Dal member an iron-bearing dyke body has been observed which resembles the intrusions of the Hammers Dal complex (Pedersen, 1975; Ulff-Møller, this report). The intrusion has a well-developed glass chill of olivine microporphyritic basalt with chromite. It is very likely that the intrusion is connected to the point 440 crater system, and that it represents a slightly contaminated iron-bearing magma, while the intermediate rock described above represents an extremely contaminated magma derived from a common parent magma.

\section{Upper basalts from the Niaqussat member}

The iron lavas are covered by voluminous, regularly columnar jointed, basaltic lavas which, after a few eruptions, totally overflowed the terrain characterized by scattered craters and thick irregular iron lavas. Fig. 9 shows how the point 440 crater was buried. The basalts are olivine microporphyritic and often nearly aphyric. They are slightly sediment contaminated and of a type recognised along the entire west coast of Disko. The basalts often show a subhorizontal flow lamination and a 'veining' which originates from a varying vesicle density and magma inhomogeneity in the lavas. The flows are mostly of pahoehoe type, sometimes transitional to aa type.

These lavas are covered by characteristic sequences of thin pahoehoe lavas of basaltic composition and by voluminous feldsparphyric or nearly aphyric basalts. The uppermost

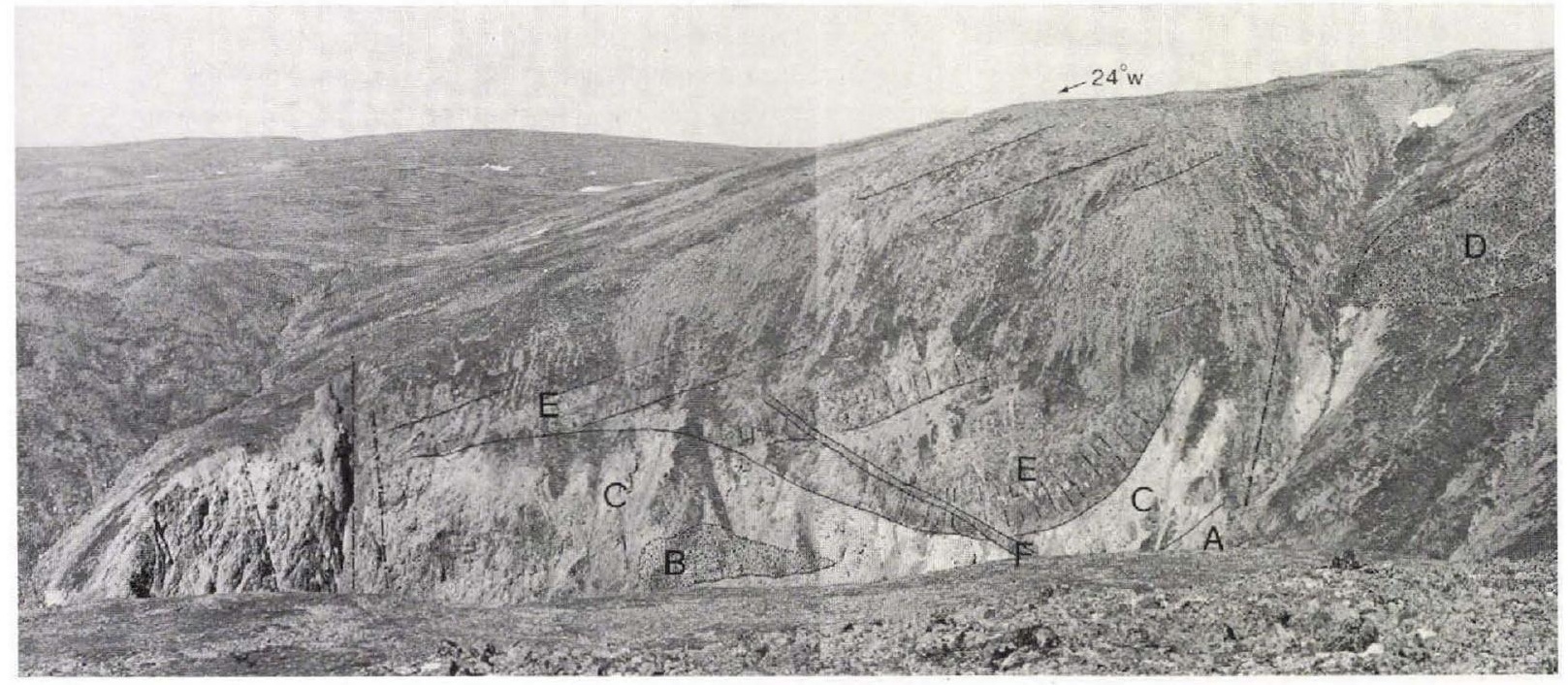

Fig. 9. The point 440 crater. An eruption site for native iron bearing intermediate rock is exposed in the cleft. To the left it is crushed by a fault zone. The sequence dips 22 to $24^{\circ} \mathrm{W}$. A: basaltic lava of the pre-crater surface. B: feeder body of iron-bearing rock. C: the oxidized, xenolith-rich, crater rock. D: thick, iron-bearing, intermediate lava, presumably erupted from the crater. E: nearly aphyric plateau basalts which buried the crater. F: dyke body cutting the sequence. Note the characteristically poorly exposed surface in the background. 
few hundred metres of lava preserved resemble in general the upper part of the Niaqussat member as described from the Mellemfjord area (Pedersen, this report).

\section{Summary of the iron-bearing rocks in the Niaqussat member}

After the Nordfjord member lavas and tuffs had been erupted, a new volcanic cycle started when olivine tholeiitic magmas from subcrustal sources flowed upwards and were trapped in sedimentary strata, which form a sequence, presumably 1 to $2 \mathrm{~km}$ thick, between Precambrian gneisses and Tertiary lavas. From regional geological work, the sedimentary sequence can be estimated to have been about 3 to $5 \mathrm{~km}$ below the palaeosurface. Magma-sediment reactions in the new-formed reservoirs occurred over large areas (more than $2000 \mathrm{~km}^{2}$ ). The largest magma masses were trapped in the areas between Gieseckes Dal and Hammers Dal, where widespread eruption sites are found. A sequence of strongly sediment contaminated lavas, about $250 \mathrm{~m}$ thick, was subsequently erupted, representing a volume of about $20-25 \mathrm{~km}^{3}$ of rocks within this area. The composition of the contaminated rocks varied irregularly with time and highly evolved rocks like rhyolites were not formed. A continuous supply of magma from subcrustal sources in this period is indicated. Larger amounts of tuff were produced than occur in the sequences of uncontaminated plateau basalts. However, the volcanism was still dominantly effusive and the explosiveness much less than generally found associated with siliceous calc-alkaline volcanoes.

The very thick intermediate lavas indicate that individual magma reservoirs were many cubic kilometres in size. However, due to the considerable tectonic disturbance in the area, volume estimates have not been made for single eruptions.

Most of the iron-bearing lavas erupted through volcanic necks as was first observed by Münther $(1952,1973)$. However the discovery of NW, NNW or N trending iron-bearing dykes and dyke tubes (Pedersen, 1973, 1975; Ulff-Møller, this report) indicate that fissure eruptions, controlled by regional tension systems (Pedersen, this report) also played an important role.

Considerable iron and sulphide mineralization should be expected below the present level of exposure in the area.

\section{References}

Henderson, G. 1973: The geological setting of the West Greenland basin in the Baffin Bay region. Pap. geol. Surv. Can. 71-23, 521-544.

Münther, V. 1952: Grafitbasalten i NV-Disko. Meddr dansk geol. Foren. 12, 159 only.

Münther, V. 1973: Results from a geological reconnaissance around Svartenhuk Halvø, West Greenland. Rapp. Grønlands geol. Unders. 50, $26 \mathrm{pp}$.

Pedersen, A. K. 1973: Report on field work along the north coast of Disko, 1971. Rapp. Grønlands geol. Unders. 53, 21-27.

Pedersen, A. K. 1975: New mapping in north-western Disko, 1972. Rapp. Grønlands geol. Unders. 69, 25-32. 